\title{
VALUE STABILITY IN LOCAL REAL ESTATE MARKETS
}

\author{
Tom KAUKO \\ Department of Geography, Norwegian University of Science and Technology - NTNU, \\ NO-7491 Trondheim, Norway \\ E-mail: tom.kauko@svt.ntnu.no ; Tel.: +47 73591919; Telefax: +47 73591878
}

Received 24 July 2009; accepted 2 December 2009

\begin{abstract}
Whenever real estate investments are considered in a more sustainable development framework, the issue is about finding the appropriate criteria of physical, social and economic sustainability. While this topic has business and social policy relevance, academic work on defining the relevant indicators is yet speculative, due to a shortage of standard definitions and relevant data. The general concept of economic sustainability of the property market comprises a variety of more particular measures. In order to design a valid methodology for assessment purposes, in this study a property value stability trend is determined for specific residential areas. This indicator is composed of property sales prices and the quality level of the existing stock in a given area. The findings from a selected demonstration of the development of price-to-quality ratios in an urban context have implications for further research as well as for practice.
\end{abstract}

KEYWORDS: Value stability; Local real estate market; Economic sustainability

\section{INTRODUCTION}

Various facets of the real estate market have been analysed in different parts of the western world - most prolifically in the US since the 1960s. Two kinds of research traditions or perspectives can be distinguished here: academia and practice. The former analyses have pertained to hedonic price/market modelling and other kinds of scientific analyses, whereas the latter often has been subject to a normative approach. Still real estate research is a relatively neglected, trivialised and undertheorised problem area pushed at the margins of economic and technical disciplines. With the increasing global significance of the sustainable development aspect this neglect needs to be corrected, given that the real estate field deals with the built environment - a substantial potential contributor to economic, social and environmental sustainability agendas (see Lorenz et al., 2008; Bramley and Power, 2009). Interestingly, within the discourse of 'sustainability science' the still vague but evolving discourse of social and economic sustainability seems to show more resonance with property investors than that of the older type of environmental-energy sustainability (Sayce et al., 2007). This gives us confidence to delve into social and economic matters at the expense of the well-trodden paths of ecologic and green arguments.

Whether the market is considered sustainable or unsustainable is not the same as classifying it as efficient or inefficient (although the two dimensions may overlap, see Kauko, 2008). In Kauko (2008), a general definition of economic sustainability was put forward. 
Using this definition a classification of housing or property market sustainability to various ordinal classes of sustainability would be a prerequisite to subsequent value modelling in order to determine whether the long-term outcome is of a healthy or distorted kind. Such a characterisation would accompany the valuation report and ideally direct the selection of valuation methodology. In the present paper, however, the topic is more particular, which requires a redefinition of the aims.

In principle, the general definition of economic sustainability (including a sustainable market) includes a number of more particular definitions that can be applied in a real estate context, such as the viability of the development project (Jones et al., 2009), the diversity of market development (Kauko, 2009b), and the stability of property value - in itself, or related to other measures such as affordability or quality. To avoid misunderstandings, only one of the mentioned definitions is applied in this contribution: namely, value stability as measured through property value (house prices) related to assessed quality indicators. Hence the main aim is to design a methodology for determining value stability (and indirectly also economic sustainability) at given locations, on the basis of property prices when these are related to other indicators. Whether we use the term 'value stability', 'sustainable market' or 'economic sustainability' here is unproblematic if we outline the exact context of the analysis. The reason for this juggling with definitions is that the broader concepts of sustainability are not universally accepted yet (see Bramley and Power, 2009, p. 45).

The secondary aim is to design a methodology for practical purposes - that is to say, decision making concerning investment feasibility. While definitions as well as hard evidence of sustainability within the real estate field are still missing, the question is whether the investment: either new development or refurbishment of the building stock, could or should be economically, physically and socially sustainable. The extent to which such issues are - or even can be - on the agenda depends on the character of the area within the city and the institutional setting where the investment takes place. One of the key aspects of this agenda is the quality level of the existing stock.

The remainder of the text is organised as follows. Section 2 justifies the sustainability imperative of a real estate strategy and the special role therein played by the location. Section 3 designs a research methodology for empirical value stability assessment which subsequently is applied empirically on priceto-quality ratios based on residential property sales and subjective quality assessment data from Amsterdam, the Netherlands. Lastly, conclusions are drawn in section 4 .

\section{VALUE STABILITY OF AREAS AS A MEASURE OF ECONOMIC SUSTAINABILITY}

As an investment class, real estate offers some promising prospects for conforming to sustainable development. To date, however, the evidence is scarce and speculative at best. Real estate economists nonetheless see enormous potential in sustainability (see Lützkendorf and Lorenz, 2007). The pivotal issue is in other words about educating the mass of real estate actors to voluntarily apply sustainability thinking. The strategy of sustainable developers such as Urban Splash Development Corporation is to reap normal profits from the real estate development, and then feed the remaining profits onto quality conscious (i.e. use value) considerations such as improved infrastructure, availability of more green areas, and providing a certain percentage of affordable housing (Bryson and Lombardi, 2009). However, this principle is debated, and it is to note that the discourse is rich and evolving.

On the other hand, the need for clearer guidelines is real. Sayce and colleagues (2007) 
underscore the importance of sustainability incentives such as taxes, which in turn requires the development of a sustainability metrics. There is widespread support among stakeholders for fiscal measures that might incentivize a movement towards more sustainable property investment and management in the UK. Sayce and colleagues point out that it is difficult to create a business case for 'sustainable property' as the would-be benefit would have to come from cost reduction, more profit or higher value, or risk reduction; currently only the last benefit really exists. Furthermore, without appropriate metrics, the business case lacks transparency for the investors; an index would generate credibility, which subsequently would lead into market transformation.

In some of the prior studies the issues under scrutiny are predominantly of a spatial kind. In essence, they concern the relationship between planning processes on one hand and the area-specific socioeconomic market characteristics on the other. Bramley and Power (2009) point out that, while the definitions and dimensions of 'sustainable real estate' are multiple, a trade-off prevails between different social and functional factors of the area, in the sense that improving the service level at the same time often worsens the social status of the area. Jones et al. (2009) in turn conclude that the viability of the project has to do with the socioeconomic factors of the neighbourhood, on top of those concerning the physical environment such as land use policy and density regulations. In other words, the characteristics of location and area are important when determining any sub-theme within real estate market sustainability.

Hedonic and buyer's choice studies alike indicate that real estate market sustainability (including value stability) is not only about the buildings and built structures, but also about the location and neighbourhood. In fact, the location share of real estate is after all at least as important determinant of investment and value as the building - although many opposite cases of course exist too (Kauko, 2006). The role of location is, however, different than the role of the building. The most obvious difference is that it cannot be changed easily in doing so, usually government cooperation is required. The government has an active role in shaping the location, which may be carried out either in a more traditional manner: by providing on-site and off-site infrastructure such as stops for public transportation, parks and recreational areas, or improved safety measures; or in accord with more modern ideas of image creation and territorial competition policy. The other key differences concern the spatial scale: the quality of the home interiors are pertinent only to the residents living there, or those potentially living there in the future, whereas the quality of the facades, street, block, vicinity and neighbourhood is subject to evaluation also by neighbours, passers-by and visitors to the neighbourhood. If it is about a city core neighbourhood the quality level affects the image and attractiveness of the whole city too (see e.g. D'Arcy and Keogh, 1998; Musterd and Deurloo, 2006; Schwegler, 2006). This way we can see the importance of value stability analysis at a well defined residential area level.

Even if we restrict the perspective to buyer's/household's choice, (re)location cannot be overlooked in the analysis of residential real estate market sustainability. Koopman (2008) refers to Schelling's segregation model based on a $2 \mathrm{D}$ grid, and argues that poorer enclaves in wealthy neighbourhoods tend to be more sustainable than pockets of prosperity in poor neighbourhoods. This is because of the different scale of the impact areas of entry and exit: namely, the prospective in-movers consider a wider area than their out-mover counterparts. In other words, when a particular micro-location (i.e. site) becomes unfavourable it triggers out-moves more than what a favourable site would trigger in-moves, because, only in the latter case, the movers are unaware of the 
experienced 'actual' drawbacks and benefits of the site and have to rely on 'hearsay' about the surrounding area (i.e. neighbourhood). Hence, if the rumour about the neighbourhood is positive it is a sufficient criterion for attracting people to even a 'bad' site.

The discussion so far shows that market sustainability is an elusive criterion in a real estate context. The core of the argument lays in the difficulty of finding adequate definitions here economic sustainability is translated into a rather narrow but manageable measure of location specific value stability. For this, certain indicators that enable analyses on market sustainability need to be identified. Could we utilise the possibilities offered by house price data for this purpose? Below such an approach is sketched. The proposed methodology deals with recording and classifying different trajectories of price-to-quality based value stability for different administrative areas in one and the same city.

\section{THE EMPIRICAL DEMONSTRATION}

In this project the aim was to classify the citywide residential property market (or more precisely, the owner occupied segment thereof) into categories with different value stability and arguably also different economic sustainability. As discussed so far, ideal data for this project comprise citywide data on (1) actual transaction prices (although it could in principle also be hypothetical value estimates); (2) subjectively assessed environmental and housing quality; and (3) income and affordability. These are defined as the data basis to build the relevant indicators of value stability, and consequently, provide the foundation for the methodology to be presented in this contribution. The documentation below is restricted to the first two kinds of data, as the third kind of data was not acquired for this study. [This is in fact the topic of a parallel study.] To analyse the value stability, we need data on property values and their descriptors; not only about the dwelling or building, but also about locations, that is to say, where certain types of sites are located. It can be argued that data on sales prices (or assessed values) of individual dwellings include plenty of useful information about two key aspects of this study: about the attractiveness of locations on one hand (i.e. preferences), and the tightness of the market on the other (i.e. containment).

When different indicators are considered it should be stressed that we must operate on the best possible data we get, while at the same time acknowledging limits in comparability and compatibility. For the present study two kinds of geographically identifiable data was required: property values and property descriptors. In principle, several different kinds of primary or secondary data sources can be utilised here. To find data on environmental features, buildings and prices is by no means always possible (this is the case in Ukraine, for example, see Kryvobokov, 2004). It may furthermore be that behavioural characteristics that define 'satisfaction' give an added value to the analysis [cf. the respective studies by Keskin (2008), Koopman (2008) and Kauko (2008)]. The data can for example be from housing demand surveys. However, the time scale of the data ought to be long enough to register changes in physical sustainability dimensions: ten to fifteen years at least, but preferably more than twenty years.

The empirical material of the study comprises data from Amsterdam, the Capital city of The Netherlands. A dataset comprising free market transactions of approximately 46,000 dwellings during 1986-2002 was prepared by the municipal tax authorities of Amsterdam (Gemeentebelastingen Amsterdam) [The same data set has been used for prior studies by the same author (see Kauko, 2004; 2005)]. This dataset is applied for the calculation of property taxes, and contains recorded information on actual property sales prices and a number of attributes such as floor-space and subjective quality indicators. The latter are constructed 
by the assessor on an ordinal ten point scale relating to the house, the maintenance and the micro-location. Marks 1 (very bad) to 10 (perfect) are given for quality, situation, and maintenance ( 0 is empty or unknown), respectively. This dataset can be conveniently disaggregated at district level (or alternatively, for each house type).

The basic principle of the method is simple: in a descriptive time-series analysis of individual transaction data the price is related to each of the three quality variables defined above. If this ratio increases, it indicates 'value instability' for a given location; if it stays constant, it indicates 'values stability', as the trends of both price and quality indicators are synchronised; and if it declines it might indicate 'money-for-stability' - that is to say, a non economically sustainable situation, even though a falling price-to-quality ratio also signals 'value instability'. The square-meter transaction price $(\mathrm{smP})$ represents an economic criterion, whereas the quality of the house (kwal), the level of maintenance (onde) and the quality of the location (ligg) refer to the three different physical quality criteria: dwelling quality, maintenance and quality of microlocation, respectively. Figure 1 shows how the steepness of the trend increases around the year 1998. Without further elaboration (as this issue goes beyond the purposes of this paper) we note that this is incidentally also the year when a market deregulation and privatisation of the Dutch housing policy begun.

Figure 1 shows clearly the measure of inflation in the Netherlands, which during the time period of collecting data was substantial. However, it is still possible to disaggregate the indicator according to spatial (and functional) variation; above all, differences between regions in the Netherlands do exist in this respect (Op't Veld et al., 2008). There are similar but lesser differences between districts within Amsterdam, in particular the districts in the Western part of the city have not experienced as steep increase than the rest of the city (Kauko, 2009a).

Four disaggregated trends are shown in Figure 2: two of them: Centrum and Oud-west (see top and second from bottom, respectively) are of similar magnitude as the aggregate trend, and, in fact, show an even steeper than average price-increase after 1998 (i.e. from an indicator value of only ca. 300 to an astonishing 700), whereas the others display a considerably less steep increase in the price-to-quality ratios (from a low 50 to a still modest 300 ).

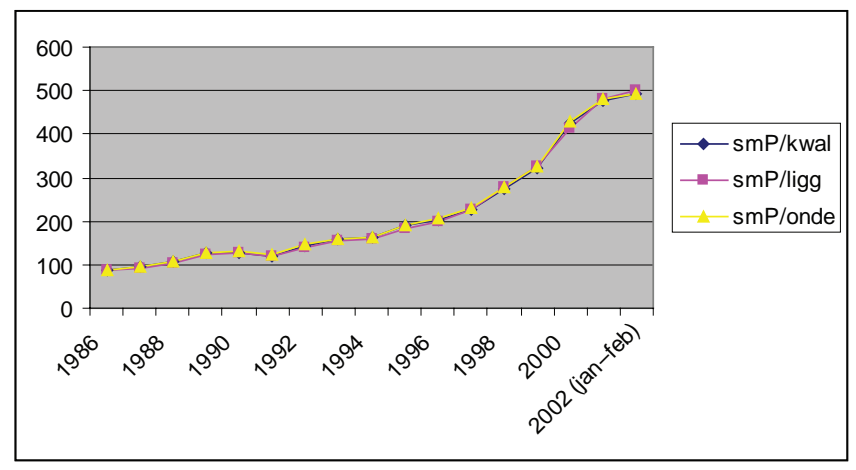

Figure 1. Time-series of the square meter price related to three different quality measures aggregated for Amsterdam.

(Note: The house prices recorded are nominal, but the real prices could be obtained by deflating with the inflation rate 1986-2002. That would be a figure in the interval of 1-4.) 


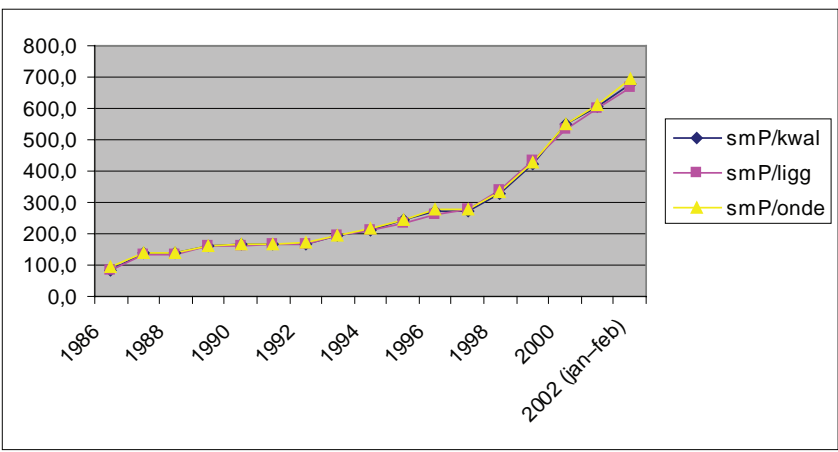

\section{Centrum}

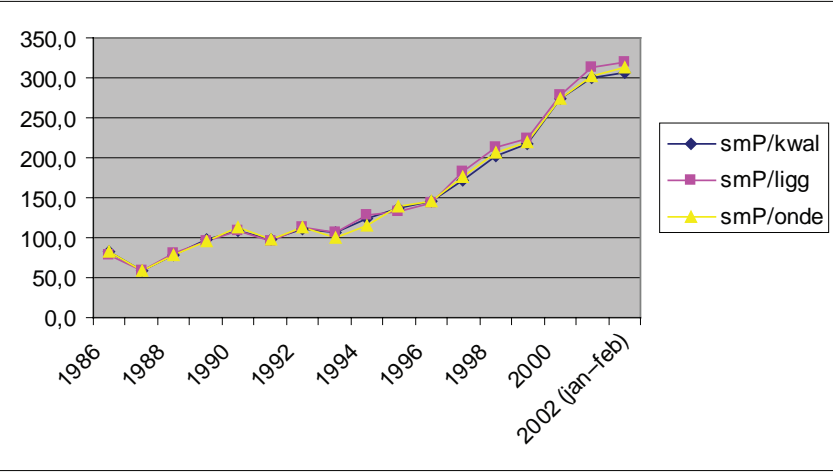

Geuzeveld-Slotermeer (in the 'Western garden cities')

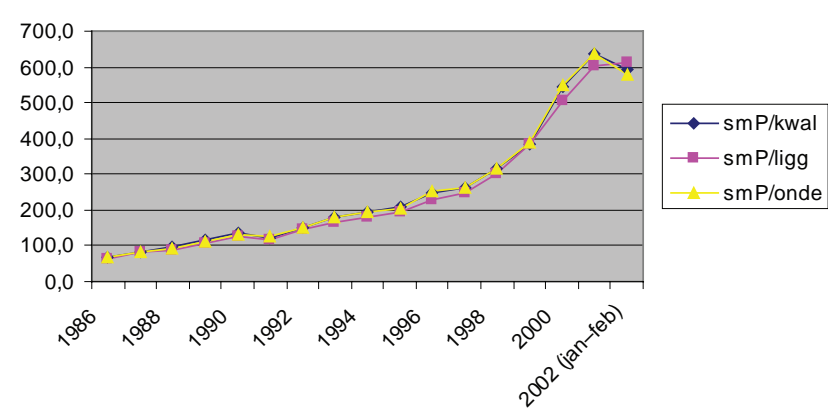

Oud-west (old-west, in the southwestern part of the outer inner city)

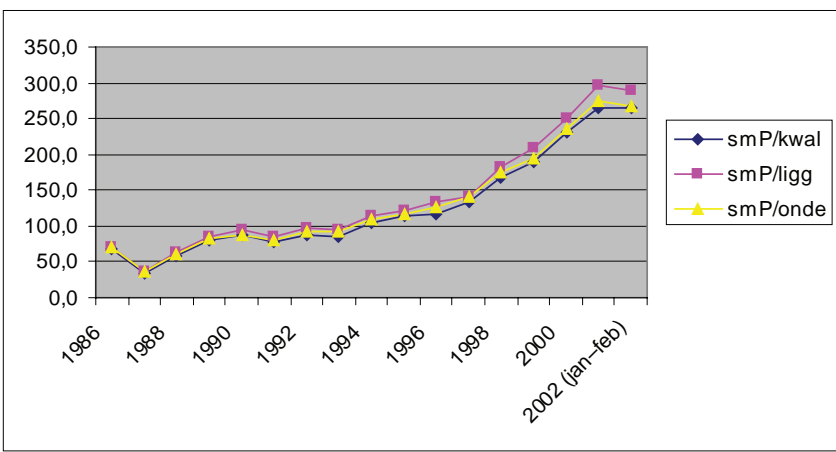

Zuidoost (southeast, annexed suburban area)

Figure 2. Time-series of the square meter price related to three different quality measures in four districts of Amsterdam 
This confirms that the price development 19862002 was more stable in some parts of Amsterdam than in others. (There is also reason to believe that similar variations exist between different property types with regard to their respective trends.)

Figure 2 shows that the uppermost graph (Centrum) has an index of more than double that of the one below (Geuzeveld-Slotermeer), which means - given our definitions - that the lower value development only is stable (or at least more stable than the upper situation). For the lower pair of graphs in Figure 2 a similar relationship is depicted: the lower situation (Zuidoost) being more stable than the upper one (Oud-west). In Figure 2 it is also worth noticing two turning points: around 1991 and 2001 respectively, when the $\mathrm{P} / \mathrm{Q}$ ratio turns downwards and thereby becomes 'more sustainable'.

Considering the validity of the method, a caveat is in place. In Amsterdam the share of owner-occupied housing is only ca. $20 \%$ of the total housing stock. This means that we have to inter- and extrapolate from this figure when the whole Amsterdam housing market is considered, which suggests a measurement error is present (the tax authorities, in particular have this problem.) Even so a method based on transaction price data gives some indication of value stability, and indirectly, tendencies for economic sustainability in different parts of Amsterdam.

\section{SUMMARY AND CONCLUSIONS}

In sustainability issues concerning land use and real estate, the issue at stake is to agree on an exact definition. Is it environmental-ecological only, or can it also - and alternatively be social-cultural, or even economic-financial? In this contribution the economic criteria is selected for scrutiny due to the need to work on the relative obscurity of this concept and deficit of research. Economic sustainability comprises at least three different sub-criteria and potential indicators: viability, diversity and value stability. The third one of these definitions is selected for this study. More specifically, the target is the value stability of certain locations (in this case, administrative areas).

The aim of the study was essentially methodological: to design indicators and criteria for measurement of 'value stability'. Here location matters alongside the building. In this paper micro-level data analysis is applied to determine sustainability: more particularly, the value stability in relation to the quality of the house or its location, as measured through transaction price together with three kinds of subjective assessments of quality. When this data is subsequently aggregated at a small spatial scale, it is possible to distinguish between trends that are, first of all, either stable (i.e. economically sustainable) or 'unstable', and further, whether the latter outcome is to be considered 'unsustainable' or 'non economically sustainable' - the rarer case when the ratio is falling. This was demonstrated using house price and subjective quality data from Amsterdam from the period 1986-2002. When we put he findings of the empirical demonstration into a broader context, we can observe that the Geuzeveld-Slotermeer district - a typical Dutch unfashionable garden city milieu - has experienced lots of social problems, but is also, given the definitions of this study, to be considered economically sustainable! This discrepancy only goes to show that we have a void in the agreed-upon terminology pertaining to this great modern-day buzzword referred to as 'sustainability'. However, the social dimension (i.e. issues related to status, negative externalities and community cohesion) was excluded from the present study. The same relation is repeated between the two lowest graphs in Figure. 2: Oud-west is in this sense less sustainable economically than Zuidoost, even if the latter surely is less sustainable socially. 
A last conclusion to make from the descriptive analyses presented is that, when analysing the role of location, it is crucial to apply an appropriate scale for the geographical or administrative area. Furthermore, similar differences across property types must be taken into consideration too. In fact, there is reason to believe there are differences between sectors with respect to the correct assessment criteria. For example, if we extend the analysis into the office market, the operational criteria will be completely different due to fundamental differences in valuation method - income capitalisation instead of market sales. Such operational level differences notwithstanding, the same philosophy of having "value stability' as one of the components of a sustainable real estate market prevails. This methodology will also be useful for real estate practitioners, when examining opportunities for steering property investments on 'the right sustainability track'.

\section{ACKNOWLEDGEMENT}

I like to thank the audience of my presentation at the ERSA meeting, Liverpool, August 27-31, 2008 and at the RSA meeting, Leuven, April 6-8, for their comments. I also like to thank Marko Kryvobokov, Marnix Koopman, David Lorenz, the panellists in the workshop Investing in a Sustainable Built Environment. Do energy efficient buildings make economic sense? (30 January, 2008, Brussels), the participants of the meeting of the EU RICS Advisory Group, (7 March, 2007, Brussels) and many others - not the least the Managing Editor Audrius Banaitis and the two anonymous referees - for their helpful suggestions for improvement of this paper.

\section{REFERENCES}

Bramley, G. and Power, S. (2009) Urban form and social sustainability: the role of density and housing type, Environment and Planning B: Planning and Design, 36(1), pp. 30-48. doi:10.1068/b33129

Bryson, J. R. and Lombardi, R. (2009) Balancing product and process sustainability against business profitability: sustainability as a competitive strategy in the property development process, Business Strategy and the Environment, 18(2), pp. 97-107. doi:10.1002/bse.640

D'Arcy, E. and Keogh, G. (1998) Territorial competition and property market process: an exploratory analysis, Urban Studies, 35(8), pp. 1215-1230. doi:10.1080/0042098984330

Jones, C., Leishman, C. and MacDonald, C. (2009) Sustainable urban form and residential development viability, Environment and Planning A, 41(7), pp. 1667-1690. doi:10.1068/a40265

Kauko, T. (2004) A comparative perspective on urban spatial housing market structure - some more evidence of local submarkets based on a neural network classification of Amsterdam, Urban Studies, 41(13), pp. 2555-2579. doi:10.1080/0042098042000294565

Kauko, T. (2005) Comparing spatial features of urban housing markets: recent evidence of submarket formation in metropolitan Helsinki and Amsterdam, DUP Science Publication, Delft, $163 \mathrm{pgs}$.

Kauko, T. (2006) What makes a location attractive for the housing consumer? Preliminary findings from metropolitan Helsinki and Randstad Holland using the analytical hierarchy process, Journal of Housing and the Built Environment, 21(2), pp. 159-176. doi:10.1007/s10901-006-9040-y

Kauko, T. (2008) From modelling tools towards the market itself - an opportunity for sustainability assessment? International Journal of Strategic Property Management, 12(2), pp. 95-107. doi:10.3846/1648-715X.2008.12.95-107

Kauko, T. (2009a) Policy impact and house price development at the neighbourhood-level - a comparison of four urban regeneration areas using the concept of 'artificial' value creation, European Planning Studies, 17(1), pp. 85-107. doi:10.1080/09654310802513963 
Kauko, T. (2009b) The housing market dynamics of two Budapest neighbourhoods, Housing Studies, 24(5), pp. 587-610. doi:10.1080/02673030903082328

Keskin, B. (2008) Hedonic analysis of price in the Istanbul housing market, International Journal of Strategic Property Management, 12, pp. $125-138$. doi:10.3846/1648-715X.2008.12.125-138

Koopman, M. (2008) The Spatial foundations of the housing market (Unpublished manuscript).

Kryvobokov, M. (2004) Urban land zoning for taxation purposes in Ukraine: possible methods under an immature land market, Property Management, 22(3), pp. 214-229. doi:10.1108/02637470410545002

Lorenz, D., d'Amato, M., Des Rosiers, F., Elder, B., van Genne, F., Hartenberger, U., Hill, S., Jones, K., Kauko, T., Kimmet, Ph., Lorch, R., Lutzkendorf, Th. and Percy, J. (2008) Sustainable property investment \& management - key issues \& major challenges, RICS, 2008. Copy available at: http://www.rics.org/Newsroom/ Keyissues/Sustainabilty/SPIM_r_230908.html [accessed 25 May 2009]

Lützkendorf, T. and Lorenz, D. (2007) "Green buildings" - just environmentally sound or also eco- nomical and a stable investment? (In Verband Deutcher Pfandbriefbanken, Real Estate Banking 2007-2008, $6^{\text {th }}$ ed. (pp. 58-68). Berlin: VBF, Association of German Pfandbrief Bank).

Musterd, S. and Deurloo, R. (2006) Amsterdam and the preconditions for a creative knowledge city, Tijdschrift voor Economische en Sociale Geografie, 97(1), pp. 80-94. doi:10.1111/j.1467-9663.2006.00498.x

Op’t Veld, D., Bijlsma, E. and van de Hoef, P. (2008) Automated valuation in the Dutch housing market: the web-application 'MarktPositie' used by NVM-realtors. (In Kauko, T. and d'Amato, M. (Eds.), Advances in Mass Appraisal Methods, Oxford: Blackwell Publishing, pp. 70-90. doi:10.1002/9781444301021.ch4

Sayce, S., Ellison, L. and Parnell, P. (2007) Understanding investment drivers for UK sustainable property, Building Research and Information, 35(6), pp. 629-643. doi:10.1080/09613210701559515

Schwegler, B. (2006) Entrepreneurial governance and the urban restructuring of a Slovakian town. In: Tsenkova, S. and Nedović-Budić, Z. (Ed.), The Urban Mosaic of Post-Socialist Europe. Space, Institutions and Policy, Heidelberg: Physica-Verlag, pp. 295-318. doi:10.1007/3-7908-1727-9_15

\section{SANTRAUKA}

\section{DARNIŲ VIETINIŲ NEKILNOJAMOJO TURTO RINKŲ KŪRIMAS}

\section{Tom KAUKO}

Intensyvejjant pasaulinės klimato kaitos darbotvarkei, investicijos į nekilnojamaji turtą daugelyje miesto teritoriju jau traktuojamos atsižvelgiant ị darnesnę plètros sistemą. Keliamas klausimas dèl fizinès, socialinės ir ekonominès investicijų darnos. Galimybe statyti naujus pastatus arba atnaujinti senus, šios veiklos igyvendinimo galimybės ir būtinybė priklauso nuo miesto rajono ir nuo paties miesto pobūdžio, nuo institucinès sąrangos ten, kur investuojama. Be to, svarbi būstuose gyvenančiu žmonių gyvenimo kokybè ir jų kasdienẻ gyvenamoji aplinka. Nors ši tema aktuali verslui ir socialinei politikai, mokslinis darbas nustatant aktualius ekonominius, fizinius ir socialinius vertinimo kriterijus tebėra spekuliatyvus, kai trūksta standartiniu apibrèžimu ir reikiamu duomenu. Šiame straipsnyje aptariami keli būdingi klausimai ir siūlomos kelios perspektyvios veiklos kryptys su netiesioginiais siūlymais kurti tyrimų metodika, taip pat praktinès kryptys. 